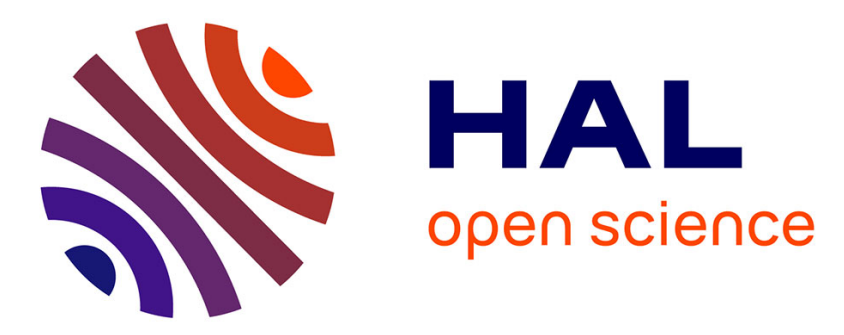

\title{
Selection for fitness at the individual or population levels: Modeling effects of genetic modifications in microalgae on productivity and environmental safety
}

Kevin J Flynn, H. Christopher Greenwell, Robert W. Lovitt, Robin J. Shields

\section{- To cite this version:}

Kevin J Flynn, H. Christopher Greenwell, Robert W. Lovitt, Robin J. Shields. Selection for fitness at the individual or population levels: Modeling effects of genetic modifications in microalgae on productivity and environmental safety. Journal of Theoretical Biology, 2010, 263 (3), pp.269. 10.1016/j.jtbi.2009.12.021 . hal-00567287

\section{HAL Id: hal-00567287 https://hal.science/hal-00567287}

Submitted on 20 Feb 2011

HAL is a multi-disciplinary open access archive for the deposit and dissemination of scientific research documents, whether they are published or not. The documents may come from teaching and research institutions in France or abroad, or from public or private research centers.
L'archive ouverte pluridisciplinaire HAL, est destinée au dépôt et à la diffusion de documents scientifiques de niveau recherche, publiés ou non, émanant des établissements d'enseignement et de recherche français ou étrangers, des laboratoires publics ou privés. 


\section{Author's Accepted Manuscript}

Selection for fitness at the individual or population levels: Modeling effects of genetic modifications in microalgae on productivity and environmental safety

Kevin J Flynn, H. Christopher Greenwell, Robert W. Lovitt, Robin J. Shields

$\begin{array}{ll}\text { PII: } & \text { S0022-5193(09)00594-3 } \\ \text { DOI: } & \text { doi:10.1016/j.jtbi.2009.12.021 } \\ \text { Reference: } & \text { YJTBI5811 }\end{array}$

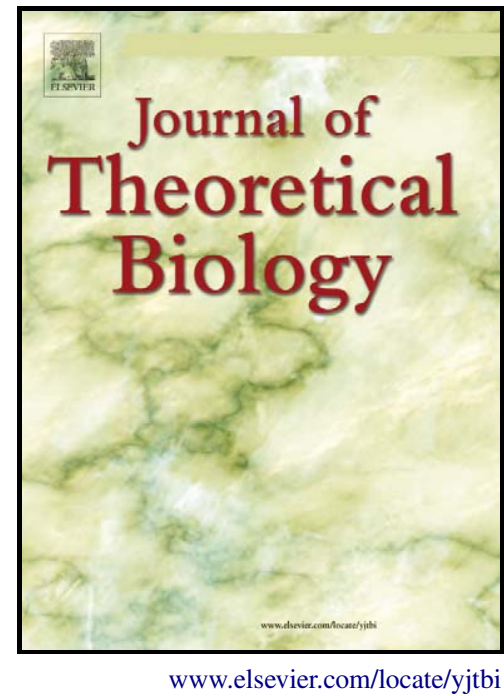

To appear in: $\quad$ Journal of Theoretical Biology

Received date: $\quad 11$ May 2009

Revised date: $\quad 30$ November 2009

Accepted date: 17 December 2009

Cite this article as: Kevin J Flynn, H. Christopher Greenwell, Robert W. Lovitt and Robin J. Shields, Selection for fitness at the individual or population levels: Modeling effects of genetic modifications in microalgae on productivity and environmental safety, Journal of Theoretical Biology, doi:10.1016/j.jtbi.2009.12.021

This is a PDF file of an unedited manuscript that has been accepted for publication. As a service to our customers we are providing this early version of the manuscript. The manuscript will undergo copyediting, typesetting, and review of the resulting galley proof before it is published in its final citable form. Please note that during the production process errors may be discovered which could affect the content, and all legal disclaimers that apply to the journal pertain. 
Selection for fitness at the individual or population levels: modeling effects of genetic modifications in microalgae on productivity and environmental safety

Kevin J Flynn ${ }^{* a}$, H Christopher Greenwell ${ }^{\mathrm{b}}$, Robert W Lovitt ${ }^{\mathrm{c}}$, Robin J Shields ${ }^{\mathrm{a}}$

${ }^{a}$ Centre for Sustainable Aquaculture Research, Department of Pure and Applied Ecology, Swansea University, Swansea SA2 8PP. ${ }^{b}$ Department of Chemistry, Durham University, Durham DH1 3LE. ${ }^{\mathrm{c}}$ School of Engineering, Swansea University, Swansea SA2 8PP.

* Corresponding author. Tel +44-1792-295726; Fax: +44-1792 295447

E-mail addresses: k.j.flynn@swansea.ac.uk (K.J. Flynn), chris.greenwell@durham.ac.uk (H.C Greenwell, r.w.lovitt@swansea.ac.uk (R.W.Lovitt), r.j.shields@swansea.ac.uk (R.J. Shields)

\section{Abstract}

A mechanistic model of microalgae is used to explore the implications of modifying microalgal chlorophyll content and photosynthetic efficiency with an aim to optimizing commercial biomass production. The models show the potential for a ten-fold increase in microalgae productivity in genetically modified versus unmodified configurations, while also enabling the use of bioreactors of greater optical depth operating at lower dilution rates. Analysis suggests that natural selection of a trait benefiting the individual (high $\mathrm{Chl}: \mathrm{C}_{\max }$; i.e. high antennae size) conflicts with artificial selection of a trait (low $\mathrm{Chl}: \mathrm{C}_{\max }$ ) of most benefit to production at the population level. The implication is that GM strains rather than strains selected from nature will be most beneficial for commercial algal biofuels production. Further, escaped GM algae populations may, depending on the specific nature of the modification, be quickly out-competed by the natural forms because individually a high Chl:C is beneficial in low light environments. However, it remains possible that changes in biochemical composition associated with genetic modification of photosystem competence, or with other selection processes to enhance commercial gain, may adversely affect the 
value of such organisms as prey for zooplankton, leading to the unwanted generation of future harmful algae.

Keywords: biofuel; GM; nutrient-limitation; photoacclimation; phytoplankton; quota-model

\section{Introduction}

Growth of microalgae for commercial gain has for many decades been the subject of intense interest (Borowitzka and Borrowitzka, 1988; Williams, 2007). Recent interest in microalgal derived biofuels has provided additional impetus, according to its pundits providing a potential ethical solution to global fuel demands and for sustainable chemicals production (Sheehan et al., 1998; Spolaore et al., 2006; Chisti, 2006, 2007; Huntley and Redalje, 2007). In theory at least, microalgae offer high productivity, high oil yields (20-70\% dry weight, Hu et al., 2008), and can be grown on marginal land not competing with food crops (Williams, 2007). Deployment of genetically modified (GM), or transgenic, microalgae will inevitably be considered (Gressel, 2008). However, the use of GM algae extends concerns leveled at GM higher plants (e.g., Johnson et al., 2007); densities run to millions of organisms $\mathrm{mL}^{-1}$, growing in 100 's or potentially 1000 's $\mathrm{m}^{3}$ of a liquid that is easily leaked, while the organisms could be transported vast distances (e.g., on a bird, or as an aerosol). On the other hand, in open-pond systems GM clones enabling better performance in monocultures may risk being out-competed by natural forms.

Most developmental work on commercialization of microalgal growth is inevitably shrouded in secrecy, with the only airing of information in carefully controlled publicity displays which cannot easily be subjected to scientific judgment. The material that is in the scientific literature includes descriptions of manipulating algal physiology to enhance commercial production such as the optimization of fatty acid profiles (Navarro-Angulo and Robledo, 1999; Li et al., 2008; Chi et al., 2009) and enhancing productivity by manipulating the photosynthetic machinery (e.g., Melis, 2009). There are also some theoretical explorations using models to aid in the optimization of bioreactor design. These models, such as that of Fernández et al. (2000), place very simple 
empirical models of biology within descriptions of bioreactors of different dimensions and dilution rates. These two features of bioreactor design, optical depth (maximum distance from illuminated surface of the water to the organism) and the dilution rate (input of new medium, and hence removal of medium containing biomass), are crucial for commercial success. The greater the optical depth of the reactor the less space is required for the installation, the lower diel temperature fluctuations and evaporation losses. The lower the dilution rate the lower the expense of growth media preparation and the higher the biomass density, so decreasing cell concentration and dewatering costs. On the down side, higher optical depths promote light limitation, while low dilution rates are linked to low growth (and hence low production) rates.

Two features of microalgal photo-physiology obviously worthy of genetic modification are apparent: i) the amount of pigment present in the organism responsible for capturing photons; ii) the efficiency with which photosystems convert sunlight into fixed C (indicated by the initial slope of the photosynthesis-irradiance curve, $\alpha^{\mathrm{Chl}}$ ). At low light, microalgae acclimate by increasing their pigment content, with chlorophyll:C (Chl:C) increasing towards a maximum $\left(\mathrm{Chl}: \mathrm{C}_{\max }\right)$. Biochemically, a high Chl:C is associated with a large photosystem antenna. While the higher the value of $\mathrm{Chl}: \mathrm{C}_{\max }$ the greater the light harvesting capacity of the individual cell, at the population level the enhanced total light absorption leads to a rapid decrease in light availability as one moves further from the illuminated surface. This event is commonly seen in nature, with the shallowing of the mixed depth being a key determinate of the initiation of algal blooms. In commercial culture of microalgae the use of bioreactors, or open ponds, of high optical depth is desirable because it increases space utilization. Unfortunately, the trade off is in decreasing algal growth rates. Restricting Chl: $\mathrm{C}_{\max }$, and the synthesis of secondary pigments, through genetic modification would decrease light absorption within the water column, allowing organisms at greater optical depth to receive more light. There has been some considerable attention paid to such modifications, through decreasing the chlorophyll antennae size (e.g., Beckmann et al., 2009; Melis, 2009). The higher the value of $\alpha^{\mathrm{Chl}}$ the more efficient is the conversion of light energy to ATP and reductant; for a given 
value of Chl:C cells can then photosynthesise at a higher rate. Further, possession of a high $\alpha^{\mathrm{Chl}}$ may mitigate against premature photoacclimation (increase in $\mathrm{Chl}: \mathrm{C}$ ) and hence premature self shading. Our understanding of the genetic underpinning of physiology now enables such possibilities to be actively explored (Mussgnug et al., 2007; Beckmann et al., 2009).

Here we apply a model of algal physiology of a type well described in the algal literature (e.g., Flynn, 2003), and applied to biogeochemical environmental investigations (e.g., Fasham et al., 2006), to consider reactor design and operation, and also the implications of genetic modification. To undertake the latter specifically requires the use of a mechanistic model of algal physiology in which physiological parameters can be altered with some level of confidence; our model provides such assurance. These models also allow a consideration of the implications of nutrient exhaustion (desired or otherwise) and of the self-shading that inevitably occurs during the growth of dense algal cultures. We explore the ramifications of modifying these two parameters $\left(\mathrm{Chl}: \mathrm{C}_{\max }\right.$ and $\left.\alpha^{\mathrm{Chl}}\right)$, consider the expected increases in yields that may be obtained from using GM algae, discuss the implications for the design and operation of cultivation system (shallow raceway or closed photobioreactor), and explore the effects of contamination of GM algae with non-GM algae, and vice versa.

\section{Model description and assumptions}

The mechanistic variable stoichiometric multi-nutrient model of microalgal growth developed by Flynn (2001) was used, equipped with the "GMFM" photoacclimation submodel described in Flynn et al. (2001). This model contains a dynamic linkage between photosynthesis and nutrient acquisition, describing changes in C-N-P biomass and $\mathrm{Chl}: \mathrm{C}$ in response to growth under nutrient and/or light limitations. This model was developed in keeping with knowledge of algal physiology and has been fitted to various experimental data sets (e.g. Flynn 2001, John and Flynn, 2002; Flynn, 2008a). It has also been applied to oceanographic scenarios (Fasham et al., 2006; Mitra et al., 2007). 
For the purpose at hand we have not sought to configure the model to describe any specific organism. The default configurations described in Flynn (2001) have been used except that the maximum growth rate $\left(\mu_{\max }\right)$ was set at two divisions a day, consistent with the use of faster growing microalgae in culture systems. Alternative configurations for testing were the same with respect to maximum growth rate, respiration rate, C:N:P quota description, etc., except with respect to the maximum value of $\mathrm{Chl}: \mathrm{C}\left(\mathrm{Chl}: \mathrm{C}_{\max }\right)$ and the initial slope of the photosynthesis-irradiance curve $\left(\alpha^{\mathrm{Chl}}\right)$. The non-genetically modified (non-GM) configuration had $\mathrm{ChlC}_{\max }$ set at $0.06\left(\mathrm{~g} \mathrm{~g}^{-1}\right)$ and $\alpha^{\mathrm{Chl}}$ at $7 \cdot 10^{-6} \mathrm{gC}^{-1} \mathrm{~g}^{-1} \mathrm{Chl} \mu \mathrm{mol}^{-1}$ photon $\mathrm{m}^{-2}$, typical for these parameters (Geider et al., 1998; Flynn, 2001; Flynn et al., 2001 and references therein). Genetic modification of $\mathrm{ChlC}_{\max }$ was considered to limit the maximum pigment content to $25 \%$ and $10 \%$ of non-GM levels. The value of $\alpha^{\mathrm{Chl}}$ were considered at 2 and 5 times the non-GM values (Table 1). The uppermost value used (35 $\mu \mathrm{gC}^{-1} \mathrm{~g}^{-1} \mathrm{Chl}_{\mu \mathrm{mol}^{-1}}$ photon $\mathrm{m}^{-2}$ ) describes a theoretical capability which, depending on the value assumed for the light absorbance coefficient, borders on or slightly exceeds the maximum theoretical value of $0.125 \mathrm{~mol} \mathrm{C}$ (mol photon $)^{-1}$.

We assume no pleiotropic effects in our hypothetical GM algae. Such a situation is unlikely in practice; Mussgnug et al. (2007) modified algal photosystems essentially achieving a decreased $\mathrm{ChlC}_{\max }$, but also causing a series of other changes associated with the restructuring of photosystems. Some of these may be advantageous while other not so. The absence of sufficient mechanistic understanding prevents us from further modifying the model structure.

While particular commercial exploitations of microalgal physiology may require induction of nutrient limitation (e.g., Shifrin and Chisholm, 1981), maximum biomass and growth rate requires initial growth to be non-nutrient-limited. The model describes the implications of nutrient limitation both directly upon growth rate, and also through impaired photosynthetic competency. Growth of the organism was simulated within media containing inorganic $\mathrm{N}$ and $\mathrm{P}$ nutrients at levels given by the classic $\mathrm{f} / 2$ medium of Guillard (1975) $\left(12.35 \mathrm{mgN} \mathrm{L}^{-1}\right.$ and $\left.1.11 \mathrm{mgP} \mathrm{L}^{-1}\right)$, or supplied with ten times these nutrient concentrations (medium 5f). Phosphate levels much above 
those in $f / 2$ may precipitate in seawater, hence $f / 2$ rather than f-medium is commonly used in marine algal culturing. Other nutrients $\left(\mathrm{Si}, \mathrm{Fe}, \mathrm{CO}_{2}\right)$ were assumed to be non-limiting in the simulations.

Cultivation was simulated in continuous flow (chemostat-style) systems at different dilution rates such that steady state growth rates equal dilution rates. Optical depths (Od) were considered over the range $0.01 \mathrm{~m}$ to $1.5 \mathrm{~m}$. In closed-tubular bioreactors (Richmond, 2003) Od equates to a tube of diameter $2 \cdot \mathrm{Od}$ assuming even illumination around the reactor tube. The larger Od values used in the simulations are most likely deliverable in raceway constructions, with light entering from the top only. Homogeneous distribution of cells was assumed within the growth vessel, as required for a chemostat-style system, and also as typically engineered in commercial reactors. Accordingly, depth integrated photosynthesis was computed as for oceanographic models (Fasham et al., 2006). Surface photon flux density (PFD) was set at $1000 \mu \mathrm{mol}$ photons $\mathrm{m}^{-2} \cdot \mathrm{s}^{-1}$, ca. half that on a cloudfree day.

In addition to simulating the growth of different microalgal configurations in different bioreactors, we also considered the implications of either a contamination of a bioreactor by a nonGM microalgal strain, or of a natural (non-GM) population by a GM strain. Again, we considered that all other physiological parameters were the same; only $\mathrm{Chl}: \mathrm{C}_{\max }$ and/or $\alpha^{\mathrm{Chl}}$ were varied. We also assume that there are no mutations of evolutional value during the 50d period of the simulation; this matter is considered further in Discussion. For the simulated contamination shown here, the dilution rate was fixed at $0.693 \mathrm{~d}^{-1}$ (i.e., $50 \% \mu_{\max }$ ); other rates do not affect the underlying results shown. Contaminations of GM-algae containing reactors operating at steady-state had the non-GM contaminant added at $1 \%$ of GM biomass. The consequences of leakage from a GM cultivation system into a watercourse of different optical depth was simulated by introduction of the GM algae into a non-GM population at $10 \%$ of the original non-GM biomass (Table 2 ).

Optimal commercial production requires maximizing both areal production $\left(\mathrm{AP}, \mathrm{gC} \mathrm{m}^{-2} \mathrm{~d}^{-1}\right)$ and volumetric production ( $\mathrm{VP}, \mathrm{gC} \mathrm{m}^{-3} \mathrm{~d}^{-1}$ ) rates, thus maximising land use, minimising water and 
nutrient consumption, and minimising harvesting costs. A system with high VP would have a very small optical depth (assuming that light was not photoinhibitory), so that light was never limiting. Inevitably such a system would have a low AP. As optical depth is increased to enhance AP, so VP decreases, but that decrease is initially not so rapid as to compensate pro rata for the increase in depth because of photoacclimation by the microalgae. Initially then, as Od is increased so AP increases also. While the relative importance of these factors will vary from application to application, as a first approximation we have used $\sqrt{\mathrm{AP} \cdot \mathrm{VP}}\left(\mathrm{gC} \mathrm{d}^{-1} \mathrm{~m}^{-2.5}\right)$ as an index of commercial production (commercial production index - CPI).

\section{Results}

\section{Bioreactor operation}

Figure 1 shows standing-stock biomass levels of systems supported by f/2 or $5 \mathrm{f}$ nutrient concentrations. Noting the different Z-axis (biomass) scales, while it is apparent that increasing nutrient availability 10 fold enables up to an order of magnitude increase in biomass, the detrimental effect of light limitation is particularly clear from the $5 \mathrm{f}$ series (Fig. $1 \mathrm{~d}-\mathrm{f}$ ). The effects of artificially decreasing Chl: $\mathrm{C}_{\max }$ through genetic modification, as shown by the $\mathrm{GM}^{\mathrm{C} 1}$ and $\mathrm{GM}^{\mathrm{C} 2}$ configurations (see Table 1) can also be seen, with enhanced production at greater optical depths being achievable because of a lessening in self-shading. Sharp transients in plots, for example at dilution $0.4 \mathrm{~d}^{-1}$ and optical depth $0.1 \mathrm{~m}$ in Fig. 1a, represent switch points between light and nutrient limitations of microalgal growth.

Figure 2 shows volumetric and areal production rates for systems supported by f/2 nutrients (CF. Fig. 1a-c). Because nutrients are exhausted in low Od systems except at very high dilution rates, light limitation becomes increasingly important as Od is increased. In such high Od systems, GM variants with low Chl: $\mathrm{C}_{\max }$ show ca. 3 fold enhanced AP (Figs. 2d-f). The coupled consequence of changes in VP and AP when employing GM configurations show a shift in peak CPI to lower dilution rates and greater Od (Fig. 2g-i). Thus, the use of the GM variant with 
decreased Chl: $\mathrm{C}_{\max }\left(\mathrm{GM}^{\mathrm{C} 1}, \mathrm{GM}^{\mathrm{C} 2}\right.$; Table 1) would enhance commercial production by permitting the use of larger (deeper) bioreactors with a lower throughput of growth medium (less media to harvest and less wastage).

Employing 10 fold higher nutrient concentrations (Fig. 3) than in f/2 media (Fig. 2) minimises the likelihood of nutrient limitation but does not eliminate it. Areal production is increased in small Od systems (note the scale of the VP values in Fig. 2, compared with Fig. 3), but at high Od light limitation is more important than nutrient limitation (Fig. 2d vs Fig. 3d). Switches between light and nutrient limitation are apparent, for example, in the maximum non-GM microalgal production at $\mathrm{Od}=0.01 \mathrm{~m}$ and at $0.3 \mathrm{~d}^{-1}$ dilution (Fig. $3 \mathrm{~d}$; also seen in Fig. 1d); nutrient limitation occurs at lower dilution rates, with light limitation at higher rates. This sharp transient occurs because nutrient-deprived cells contain less pigment, lessening light absorbance by the water column suspension, so increasing the likelihood of nutrient limitation further. Using a GM variant with low Chl: $\mathrm{C}_{\max }\left(\mathrm{GM}^{\mathrm{C} 1}, \mathrm{GM}^{\mathrm{C} 2}\right.$; Table 1) increases AP in low Od systems in $5 \mathrm{f}$ versus $\mathrm{f} / 2$ medium, but there is little difference at the greatest Od as these systems are severely light limited (e.g. Fig. 3f vs. 2f).

While the use of GM configuration with decreased Chl: $\mathrm{C}_{\max }$ has a clear advantage, with a greatly increased volumetric and hence areal production over the nonGM counterpart (Fig. 3), deploying GM microalgae with elevated $\alpha^{\mathrm{Chl}}$ has far less impact (Fig. 4). Using elevated $\alpha^{\mathrm{Chl}}$ increases production greatly in low Od systems, in which light is less limiting. However, at high Od the advantage is most apparent at high dilution rates. The explanation is that this GM configuration $\left(\mathrm{GM}^{\alpha 1}, \mathrm{GM}^{\alpha 1}\right)$ still has a high $\mathrm{Chl}: \mathrm{C}_{\max }($ Table 1) and hence self-shading remains a limiting factor for population growth. As described above, sharp transients seen at some dilution rates reflect transitions from nutrient to light limitations. The values of CPI for these configurations (not shown) are high only within small Od systems (as would be deployed in tubular photobioreactors; Richmond, 2003). 
Combining elevated $\alpha^{\mathrm{Chl}}$ and decreased $\mathrm{Chl}: \mathrm{C}_{\max }$ in a GM organism has the greatest potential for increasing production (Fig. 5), with production as much as 10 fold greater than when using the non-GM configuration over a wide range of dilution rates and optical depths (e.g., nonGM vs $\mathrm{GM}^{\mathrm{C} 2 \alpha 2}$ ). The improvement is most apparent from the CPI values for various microalgal configurations shown in Fig. 6. The commercial advantage is not simply with elevated production, but also because production costs would be decreased through the use of larger Od reactors operating at lower dilution rates and hence requiring less medium to prepare and subsequently to process.

\section{Contamination simulations}

Contamination of a GM system by a native (non-GM) variant results in the elimination of GM variants with low Chl: $\mathrm{C}_{\max }$ (Fig. 7a). This event is most rapid in a high Od bioreactor, where the high $\mathrm{Chl}: \mathrm{C}_{\max }$ of the non-GM clone enables them to make better use of available light, while simultaneously shading out the GM clone. In contrast, contamination of a GM clone exhibiting a high $\alpha^{\text {Chl }}$ by the non-GM clone has no impact on the GM clone (Fig. 7b); here the non-GM contaminant is eliminated because for a given photon flux density at the cell surface, $\mathrm{GM}^{\alpha}$ converts more energy to growth. Contamination of a GM clone exhibiting low $\mathrm{Chl}: \mathrm{C}_{\max }$ plus high $\alpha^{\mathrm{Chl}}$ (clone $\mathrm{GM}^{\mathrm{C} 2 \alpha 2}$ ) by the non-GM variant is likely only at high Od (Fig. 7c). However, as this GM configuration allows the commercial exploitation of such high Od bioreactors, the threat is potentially important.

Simulations of the implications of the release of GM algae into watercourses of different depths were considered at a lower nutrient regime (see Table 2), commensurate with the likely nutrient load in such waters. Escape of a GM organism with a low $\mathrm{Chl}: \mathrm{C}_{\max }$ appears of no danger as it is out-competed by the natural strain (Fig. 7d). A GM hybrid, with both low Chl: $\mathrm{C}_{\max }$ and high $\alpha^{\mathrm{Chl}}$, a form of most commercial value, also appears to be of minimal danger to a natural population (Fig. 7f). This is especially so as in most natural habitats Od would be greater than in cultivation systems and so the presence of a high $\mathrm{Chl}: \mathrm{C}_{\max }$ in the natural strain would prove to be of greatest 
importance in competing for light absorbance. In contrast, escape of a GM organism with an elevated $\alpha^{\mathrm{Chl}}$ results in the success of the GM strain at the expense of the non-GM form (Fig. 7e).

\section{Discussion}

To our knowledge this is the first application of a full physiologically based mechanistic model of microalgal to the subject of the commercial exploitation of these organisms. Not only does it reveal some facets of the potential of GM microalgae for commercial exploitation, and of the associated risks, but it also shows an interesting feature of evolution.

\section{Potential for enhanced production using GM microalgae}

Genetic manipulation is thought to be essential to realise maximum commercial microalgal production (Chisti, 2007; Rosenberg et al., 2008). However, there has been little reported in the literature on modification of organisms to enhance productivity (e.g. for lipid production, Dunahay et al., 1996), other than for photosynthesis (e.g., Beckmann et al., 2009) most likely due to commercial sensitivities. Though others have produced models for algal productivity in photobioreactors (e.g. Acién Fernández et al., 1998; Camacho Rubio, 2002), ours in the first to consider the effects of genetic modification. Our simulations indicate optimum production for nonGM algae at a dilution rate of $c a .50 \%$ of maximum growth rate, depending on whether nutrients become exhausted. A potential 10 fold enhancement in microalgal production through genetic modification of photosynthetic parameters is simulated (Figs. 1-3, 5, 6), with deployment of clones with a lower Chl: $\mathrm{C}_{\max }$ decreasing the optimum dilution rate and increasing the optimum Od (e.g.,

Fig. 2). These operational changes are highly desirable, providing greater areal production (needing less land), and less use of water (also requiring less effort to harvest the microalgae).

It is worth noting that the levels of production simulated here assumes that dissolved inorganic carbon (DIC; primarily $\mathrm{HCO}_{3}{ }^{-}$and $\mathrm{CO}_{2}(\mathrm{aq})$ ) is non-limiting. Freshwater contains little DIC, and even seawater contains only $2 \mathrm{mM}$. Marine phytoplankton growth becomes limited by DIC at values below ca. $0.2 \mathrm{mM}$ (Clark and Flynn, 2000). To support the consumption of the $\mathrm{N}$ from $5 \mathrm{f}$ 
medium (123.5 $\mathrm{g} \mathrm{N} \mathrm{m}^{-3}$ ) requires the input of ca. $740 \mathrm{~g} \mathrm{C}$ as DIC per cubic metre. For the optimal dilution rate indicated by the simulations (ca. $0.5 \mathrm{~d}^{-1}$ ), this equates to a need to dissolve into the growth medium ca. $700 \mathrm{~L} \mathrm{CO}_{2} \mathrm{~m}^{-3} \mathrm{~d}^{-1}$ while retaining a constant medium $\mathrm{pH}$, and temperature.

\section{Natural selection versus GM}

The fundamental basis of life on this planet is thought to have been fixed some $2 \mathrm{Ga}$ ago (Shi et al., 2005), with natural selection then optimising the packaging of these key biochemical processes. These ancient so-called frozen metabolic accidents essentially fixed the molecular structure of key functional biomolecules, including processes such as the functionality of the photosynthetic Z-scheme that set $\alpha^{\mathrm{Chl}}$ at the biochemical level (although the overall cellular packaging of the processes and presence of accessory pigments affect the expression of $\alpha^{\mathrm{Chl}}$ at the cellular level). To alter the products of genes coding for such structures to enhance efficiency may be expected now to require a wholesale rebuilding of the functional proteins and support structures, rather than a relatively simple series of minor changes. This situation could be likened to modifying a helicopter to a jet fighter; both fly but the structures are so different that one could not possibly convert one to the other by substitution of components. While mutation to improve existing structures has almost certainly gone as far as it can, if it was possible to start with a synthetic alternative, then the chances of constructive mutation would again be opened.

On the other hand, expression (synthesis) and regulation of photosystems, which is in part reflected by changes in $\mathrm{Chl}: \mathrm{C}$ during photoacclimation, does represent a characteristic more amenable to natural selection, and also to genetic modification (e.g., see Mussgnug et al. 2007). Indeed, there has been considerable interest in altering the size of the Chl antennae directed towards decreasing the wastage of energy by cells with a high Chl content when exposed to high light (reviewed by Melis, 2009). Beckmann et al. (2009) have undertaken this type of work, and indeed report the types of advantages that we see with our simulated microalgae, with a increased growth in dense suspensions due to an increased light penetration with less self-shading within the population. 
For biofuel applications, microalgae grown in high density suspensions are subjected to alternating very high light and near darkness as they move through the optical depth. In nature, the optical depth is much greater, the biomass densities much lower, and cells develop a high Chl content when subjected to non-saturating light. This is a dynamic process that occurs over dayscales of time; this type of event in nutrient-replete phytoplankton can be seen in the data of Anning et al., (2000) which has been simulated using the model deployed here (Flynn et al., 2001). It is interesting to compare the areal production values projected in Fig. $2 \mathrm{~d}$ and $3 \mathrm{~d}$, for nonGM configured microalgae growing in $\mathrm{f} / 2$ and $5 \mathrm{f}$ media, with those in highly productive oceanic waters (Sarmineto and Gruber, 2006). These values, ca. $5 \mathrm{~g} \mathrm{C} \mathrm{m}^{-2} \mathrm{~d}^{-1}\left(\equiv 18250 \mathrm{~kg} \mathrm{C}\right.$ hectare $\left.\mathrm{yr}^{-1}\right)$ under shallow water high nutrient conditions in simulated bioreactors compare well with productions of around $100 \mathrm{~mol} \mathrm{C} \mathrm{m}^{-2} \mathrm{yr}^{-1}\left(=3.29 \mathrm{~g} \mathrm{C} \mathrm{m}^{-2} \mathrm{~d}^{-1}\right)$ for oceanic up-welling zones which are low nutrient, light limited zones of 10's metres depth. This suggests that even if we could fertilize the worlds ocean to enhance carbon-drawdown (e.g., through addition of iron; Buesseler et al., 2004), or indeed to enhance production in other ways, the current physiological configuration of microalgae itself will limit areal carbon fixation.

Light is the most fundamental "nutrient" likely to limit microalgal growth, especially in most water bodies in which the mixing depth may approach or exceed the critical depth $\left(D_{\text {crit }}\right.$, where depth and day integrated photosynthesis equals respiration). For the individual microalga the capture of light is critical, and selection (all else being equal) would be expected to favour cells with a high Chl: $\mathrm{C}_{\max }$. However, for the population, the self-shading that accompanies the development of cells of high Chl:C is itself self limiting. That is why the genetic modification of photoacclimation to limit $\mathrm{Chl}: \mathrm{C}_{\max }$ results in greater production (Figs. 1-3), and is why there have been attempts to capitalise on such an approach (Melis, 2009). The use of genetically modified microalgae was suggested and explored over a decade ago (e.g. for lipid production - Dunahay et al., 1996). Indeed it is considered that the use of GM microalgae, like the deployment of GM higher plants, may be essential (Gressel, 2008) in order to boost production levels. 
The results from our analysis suggest that the greatest commercial production from microalgae is to be achieved not by selection from amongst naturally occurring strains, but through genetic modification of their photosynthetic capability. The reason for this is that natural selection has worked in a direction totally contrary to that required to optimise microalgal bioreactor production. Microalgae with higher $\mathrm{Chl}: \mathrm{C}_{\max }$ may have a poorer production as a population, but they are fitter individually; a low Chl: $\mathrm{C}_{\max }$ is only advantageous in clonal microalgal blooms. Here, fitness is characterised by an ability to out-grow competitors under various conditions of light and nutrient availability. In traditional chemostats, fitness $\left(\mathrm{R}^{*}\right)$ can be defined as $R^{*}=\frac{D \cdot K_{\mu}}{\mu_{\max }-D}$, where $\mathrm{D}$ is dilution rate, $\mu_{\max }$ the maximum growth rate, and $\mathrm{K}_{\mu}$ is the half saturation constant for growth (Grover, 1997). However, outside of a single-nutrient limited chemostat, as in an algal race-way, $\mathrm{K}_{\mu}$ is not a constant, but (because it is a function of total cell physiology) varies according to the interrelationship between nutrient and light limitations. The importance of this interaction can be seen in the break-points in the $3 \mathrm{D}$ plots where nutrient rather than light limitation becomes important, not least because at that point the pigment level in the cell declines affecting light levels in the whole system.

It seems reasonable to expect that in nature, best advantage for the individual is given by a high $\alpha^{\mathrm{Chl}}$ together with a high $\mathrm{Chl}: \mathrm{C}_{\max }$, a mix that in bioreactors pays little dividend as the advantage in having a higher $\alpha^{\mathrm{Chl}}$ is rather lost if $\mathrm{Chl}: \mathrm{C}_{\max }$ also remains high (Fig. 4). The exponential rate of light absorbance through the water column rapidly removes the benefit in photochemical efficiency. In any case, because the value of $\alpha^{\mathrm{Chl}}$ is a function of photosystem molecular structure, genetic modification of $\alpha^{\mathrm{Chl}}$ presents a severe challenge. Fortunately from the point of view of employing genetic modification to enhance commercial microalgal production (as explained above), modifying (decreasing) $\mathrm{Chl}: \mathrm{C}_{\max }$, rather than maximising $\alpha^{\mathrm{Chl}}$, shows most promise for enhancing microalgal productivity. As the packaging of photosystems within a microalga also occupies much space within the cell, the setting of a decreased $\mathrm{Chl}: \mathrm{C}_{\max }$ has 
implications also for increasing the cellular content of commercially useful chemicals. How all this may interact with cell size, given that light-limited cells are usually smaller (Falkowski and Raven, 1997), is not clear.

\section{Environmental safety: competition between non-GM and GM strains}

Given all the above, it is all the more fortuitous that while the escape of a GM clone with enhanced $\alpha^{\mathrm{Chl}}$ appears dangerous (Fig. 7e), GM clones with lowered Chl: $\mathrm{C}_{\max }$, while being excellent in a cultivation system, are disadvantaged in competition with their non-GM counterparts (Fig. 7d, f). Taken at face value this could be taken to indicate that such genetic modification would pose no threat to nature; at least the basic tenet of genetically modifying microalgae with respect to the extent of photoacclimation (decreasing $\mathrm{Chl}: \mathrm{C}_{\max }$ ) appears to pose minimal risk. Indeed, the greater problem appears to be the risk of contamination of such GM-containing cultivation system with naturally selected microalgae in open reactors (Fig. 7a, c). However, there are several important caveats for the above assumptions.

Firstly, it assumes that there is no useful mutation within the GM algae over the period of the interaction and hence that competition is more important that microevolution. This assumption is not unreasonable over the simulated period of 2 month duration. Secondly, it is most unlikely that the only feature of a microalga to be altered in genetic modification would be features affecting photosynthesis, such as the antenna size (affecting $\mathrm{Chl}: \mathrm{C}_{\mathrm{max}}$ ). It is likely that other features affecting the biochemical composition would be altered for commercial gain, most notably the fatty acid content (Dunahay et al., 1996), which is also a target for modification to enhance biofuel production. Such changes will likely alter the value of the organism as food for the zooplankton that in nature control algal bloom potential through top-down regulation. It may also affect allelopathic interactions between species of microalgae. Indeed, the modification of factors other than those leading to enhanced photosynthesis are probably most dangerous, not least because it would appear that an advantageous mutation within a GM strain originally constructed to minimise self-shading (i.e. low $\mathrm{Chl}: \mathrm{C}_{\max }$ ) would be to increase $\mathrm{Chl}: \mathrm{C}_{\max }$ back towards values in the original strain. It is 
notable that many environmentally successful microalgae are not those that outwardly seem best configured for growth in competition with other microalgae (Mitra and Flynn, 2005). Surviving grazing pressure has proven to be the most important facet affecting the success of alien plant species (e.g. Kimball and Schiffman, 2003; Vavra et al., 2007); we may yet tamper with the genetic configuration of microalgae at our peril, unwittingly producing new strains of harmful algae.

\section{Acknowledgements}

The authors thank PJ LeB Williams for his comments on an earlier draft of this work, and also several anonymous reviewers for their insightful comments.

\section{References}

Acién Fernández, F.G., García Camacho, F., Sánchez Pérez, J.A., Fernández Sevilla, J.M., Molina Grima, E., 1998. Modeling of biomass productivity in tubular photobioreactors for microalgal cultures: effects of dilution rate, tube diameter, and solar irradiance. Biotechnol. Bioeng., 58, 605-616.

Anning, T., Macintyre, H. L., Pratt, S. M., Sammes, P. J., Gibb, S., Geider, R. J. 2000. Photoacclimation in the marine diatom Skeletonema costatum. Limnol. Oceanogr. 45, 18071817.

Beckmann, J., Lehr, F., Finazzi, G., Hankamer, G., Posten, C., Wobbe L., Kruse, O., 2009. Improvement of light to biomass conversion by de-regulation of light-harvesting protein translation in Chlamydomonas reinhardtii. J. Biotech. 142, 70-77

Borowitzka, M.A., Borowitzka, L.J., 1988. (eds) Micro-algal Biotechnology. Cambridge University Press: Cambridge, U.K.

Buesseler, K.O., Andrews, J.E., Pike, S.M., Charette, M.A., 2004. The Effects of Iron Fertilization on Carbon Sequestration in the Southern Ocean. Science 304, 414 - 417

Camacho Rubio, F., García Camacho, F., Fernández Sevilla, J.M., Chisti, Y., Molina Grima, E., 
2002. A mechanistic model of photosynthesis in microalgae. Biotechnol. Bioeng., 81, 459473.

Chi, Z.Y., Liu, Y., Frear, C., Chen, S.L., 2009. Study of a two-stage growth of DHA-producing marine algae Schizochytrium limacinum SR21 with shifting dissolved oxygen level. Applied Microbiology And Biotechnology 81, 1141-1148.

Chisti, Y., 2006. Microalgae as sustainable cell factories. Environ. Eng. Manag. J., 5, 261-274.

Chisti, Y., 2007. Biodiesel from microalgae. Biotechnol. Adv., 25, 294-306.

Clark, D.R., Flynn, K.J., 2000. The relationship between the dissolved inorganic carbon concentration and growth rate in marine phytoplankton. Proc. Roy. Soc. Lond. B 267, 953959.

Dunahay, G.T., Jarvis, E.E., Dais, S.S., Roessler, P.G., 1996. Manipulation of microalgal lipid production using genetic engineering. App. Biochem. Biotech., 57/58, 223-231.

Falkowski, P.G., Raven, J.A., 1997. Aquatic Photosynthesis. Blackwell Science, London.

Fasham, M.J.R., Flynn, K.J., Pondaven, P., Anderson, T.R., Boyd, P.W., 2006. Development of a robust ecosystem model to predict the role of iron on biogeochemical cycles: a comparison of results for iron-replete and iron-limited areas, and the SOIREE iron-enrichment experiment. Deep-Sea Research I, 53, 333-366.

Flynn, K.J., 2001. A mechanistic model for describing dynamic multi-nutrient, light, temperature interactions in phytoplankton. J. Plankt. Res. 23, 977-997.

Flynn, K.J., 2003. Modelling multi-nutrient interactions in phytoplankton; balancing simplicity and realism. Prog. Oceanogr. , 56, 249-279.

Flynn, K.J., 2008a. The importance of the form of the quota curve and control of non-limiting nutrient transport in phytoplankton models. J. Plankt. Res. 30, 423-438.

Flynn, K.J., 2008b. Attack is not the best form of defense; lessons from harmful algal bloom dynamics. Harmful Algae 8, 129-139. 
Flynn, K.J., Marshall, H., Geider, R.J., 2001. A comparison of two N-irradiance models of phytoplankton growth. Limnol. Oceanogr. , 46, 1794-1802.

Gressel, J., 2008. Transgenics are imperative for biofuel crops. Plant Sci., 174, 246-263.

Grover, J.P., 1997. Resource Competition; Chapman \& Hall, London

Guillard, R.R., 1975. Culture of phytoplankton for feeding marine invertebrate. In: Smith, W. L., Chanley, M. H. (eds.) Culture of marine invertebrate animals. Plenum Press. New York, p. 29-80.

Hu, Q., Sommerfeld, M., Jarvis, E., Ghirardi, M., Posewitz, M., Seibert, M., Darzins, A., 2008. Microalgal triacylglycerols as feedstocks for biofuel production: perspectives and advances. Plant J., 54, 621-639

Huntley, M.E., Redalje, D.G., 2007. $\mathrm{CO}_{2}$ mitigation and renewable oil from photosynthetic microbes: a new appraisal. Mit. Adapt. Strat. Glob., 12, 573-608.

John, E.H., Flynn, K.J., 2002. Modelling changes in paralytic shellfish toxin content of dinoflagellates in response to nitrogen and phosphorus supply. Mar. Ecol. Prog. Ser. 225, 147-160.

Johnson, K.L, Raybould, A.F., Hudson, M.D., Poppy, G.M., 2007. How does scientific risk assessment of GM crops fit within the wider risk analysis? Trends Plant. Sci. 12, 1-5.

Kimball, S., Schiffman, P.M., 2003. Differing effects of cattle grazing on native and alien plants. Cons. Biol. 17, 1681-1693.

Li, Y.Q., Horsman, M., Wang, B., Wu, N., Lan, C.Q., 2008. Effects of nitrogen sources on cell growth and lipid accumulation of green alga Neochloris oleoabundans. App. Microbiol. Biotec. 81, 629-636.

Melis, A., 2009. Solar energy conversion efficiencies in photosynthesis: Minimizing the chlorophyll antennae to maximize efficiency. Plant Sci. 177, 272-280.

Mitra, A., Flynn, K.J., 2005. Predator-prey interactions: is "ecological stoichiometry" sufficient when good food goes bad? J. Plankt. Res. 27, 393-399. 
Mitra, A., Flynn, K.J., Fasham, M.J.R., 2007. Accounting correctly for grazing dynamics in Nutrient-Phytoplankton-Zooplankton models. Limnol. Oceanogr. 52, 649-661.

Mussgnug, J.H., Thomas-Hall, S., Rupprecht, J., Foo, A., Klassen, V., McDowall, A., Schenk, P. M., Kruse, O., Hankamer, B., 2007. Engineering photosynthetic light capture: impacts on improved solar energy to biomass conversion. Plant Biotec. J. 5, 802-814.

Navarro-Angulo, L., Robledo, D., 1999. Effects of nitrogen source, N : P ratio and N-pulse concentration and frequency on the growth of Gracilaria cornea (Gracilariales, Rhodophyta) in culture. Hydrobiologia 399, 315-320.

Richmond, A., 2003. Handbook of microalgal culture. Blackwell, U. K.

Rosenberg, J.N., Oyler, G.A., Wilkinson, L., Betenbaugh, M.J., 2008. A green light for engineered algae: redirecting metabolism to fuel a biotechnology revolution. Curr. Opin. Biotech., 19, 430-436.

Sarmineto, J.L., Gruber, N., 2006. Ocean biogeochemical dynamics. Princeton University Press, New Jersey, U.S.A.

Sheehan, J., Dunahay, T., Benemann, J., Roessler, P., 1998. A look back at the U.S. department of energy's aquatic species program - biodiesel from algae. National Renewable Energy Institute, NREL/TP-580-24190

Shi, T., Bibby T.S., Jiang, L., Irwin, A.J., Falkowski, P.G., 2005. Protein interactions limit the rate of evolution of photosynthetic genes in cyanobacteria. Mol. Biol. Evol. 22, 2179-2189.

Shifrin, N.S., Chisholm, S.W., 1981. Phytoplankton Lipids: Interspecific differences and effects of nitrate, silicate and light-dark cycles. J. Phycol. 17, 374-384.

Spolaore, P., Joannis-Cassan, C., Duran, E., Isambert, A., 2006. Commercial applications of microalgae. J. Biosci. Bioeng., 101, 87-96.

Vavra, M., Parks, C.G., Wisdom, M.J., 2007. Biodiversity, exotic plant species, and herbivory: The good, the bad, and the ungulate. Forest Ecol. Man. 246, 66-72.

Williams, P.J.L., 2007. Biofuel: microalgae cut the social and ecological costs. Nature, 450, 478. 


\section{Legends}

Table 1. Differences between the configurations of microalgae employed in this work. Other than setting the maximum growth rate at $1.386 \mathrm{~d}^{-1}$ (i.e., 2 divisions a day) all other parameters were as described in Flynn (2001) and Flynn et al. (2001). Chl: $\mathrm{C}_{\max }\left(\mathrm{g} \mathrm{Chl} \mathrm{g}^{-1} \mathrm{C}\right)$ is the maximum chlorophyll content in nutrient replete cells. $\alpha^{\mathrm{Chl}}\left(\mu \mathrm{gC}^{-1} \mathrm{~g}^{-1} \mathrm{Chl}_{\mu} \mathrm{mol}^{-1}\right.$ photon $\mathrm{m}^{-2}$ ) is the initial slope of the photosynthesis-irradiance curve.

Table 2. Configuration of contamination systems. For descriptions of the microalgae configurations, see Table 1. The macro nutrients $\mathrm{N}$ and $\mathrm{P}$ were as defined in the f growth medium described by Guillard (1975); $\mathrm{N}$ at $24.7 \mathrm{~g} \mathrm{~m}^{-3} ; \mathrm{P}$ at $2.22 \mathrm{~g} \mathrm{~m}^{-3}$. All other nutrients assumed to be in excess.

Fig. 1. Biomass standing stock for systems supported by $\mathrm{f} / 2$ nutrients (panels a-c), or by $5 \mathrm{f}$ medium (panels d-f), simulating growth of nonGM, $\mathrm{GM}^{\mathrm{C} 1}$ or $\mathrm{GM}^{\mathrm{C} 2}$ microalgae (see Table 1 for organism configurations).

Fig. 2. Volumetric (VP) and areal (AP) production in the $\mathrm{f} / 2$ systems. See Fig.1 (a-c) for standingstock densities. Note the direction of the optical depth scales. Also shown is the commercial production index $(\mathrm{CPI}=\sqrt{\mathrm{AP} \cdot \mathrm{VP}})$.

Fig. 3. Volumetric (VP) and areal (AP) production in the $5 \mathrm{f}$ systems. See Fig.1 (d-f) for standingstock densities.

Fig. 4. Volumetric production (VP) for systems grown on $5 \mathrm{f}$ nutrients, simulating growth of nonGM, $\mathrm{GM}^{\alpha 1}$ or $\mathrm{GM}^{\alpha 2}$ microalgae (see Table 1 for algal configurations). Cf. Fig. 3 a-c; Fig. $3 \mathrm{~b}$ and $\mathrm{c}$ show production with GM configurations with limited $\mathrm{Chl}: \mathrm{C}_{\max }$, while panels (b) and (c) here show the implications of enhancing $\alpha^{\text {Chl }}$.

Fig. 5. Volumetric (VP) and areal (AP) production in 5 f nutrient systems containing nonGM or GM configured microalgae with both decreased Chl: $\mathrm{C}_{\max }$ and enhanced $\alpha^{\mathrm{Chl}}$. (See also Table 1). Note the direction of the optical depth scales. 
Fig. 6. Commercial production index $(\mathrm{CPI}=\sqrt{\mathrm{AP} \cdot \mathrm{VP}})$ for various microalgal configurations supported by $5 \mathrm{f}$ nutrients.

Fig. 7. Changes in percentage biomass of either GM contaminated by nonGM (a-c), or of nonGM contaminated by GM configured microalgae (d-f) over time following the simulated contamination event. See also Table 2. 

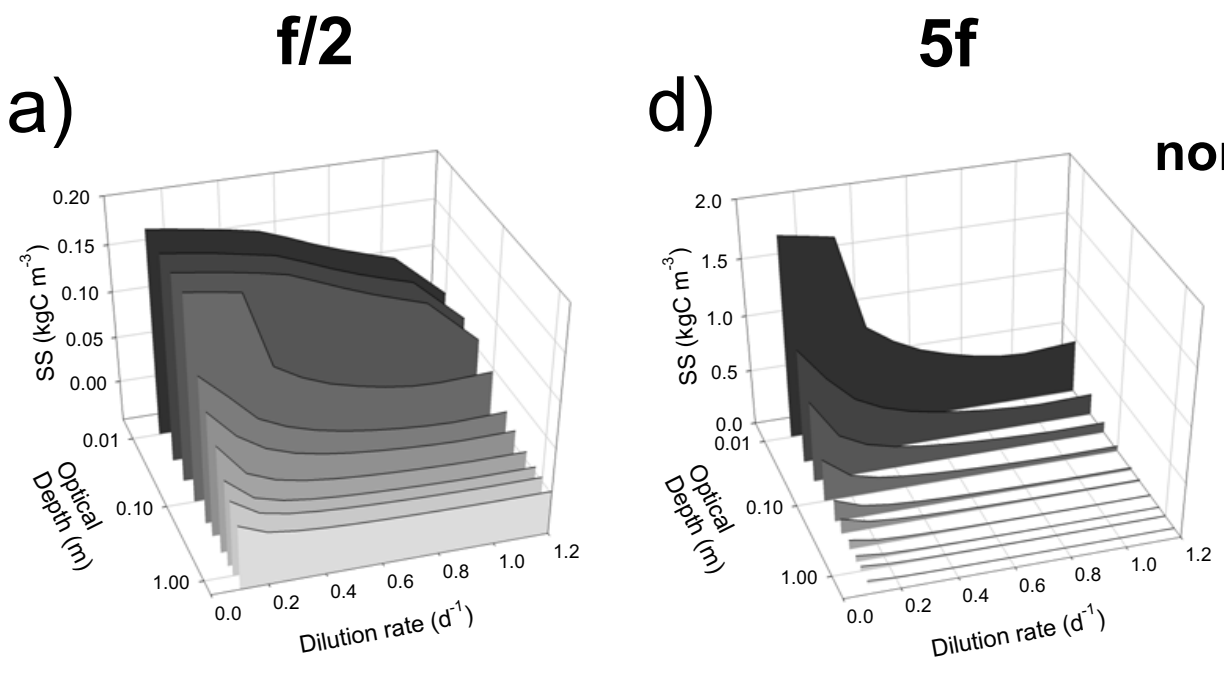

b

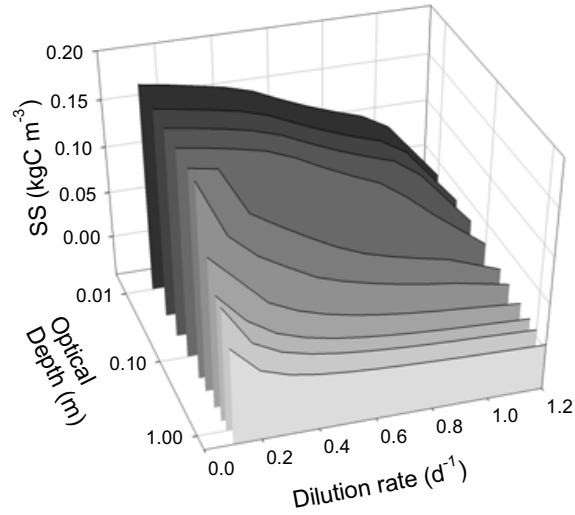

c)

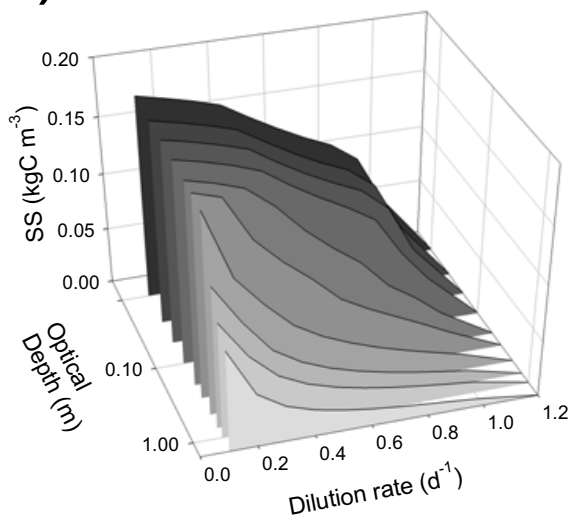

e)

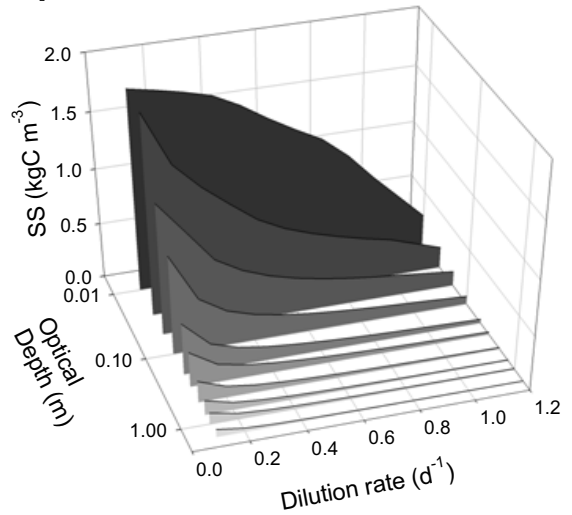

f)

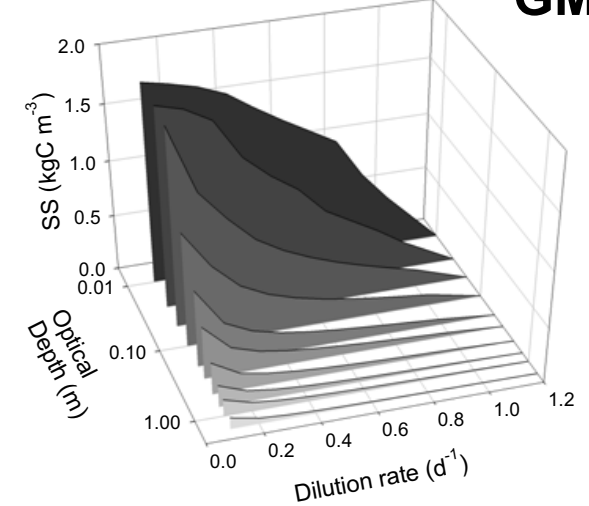

FIG. 1 

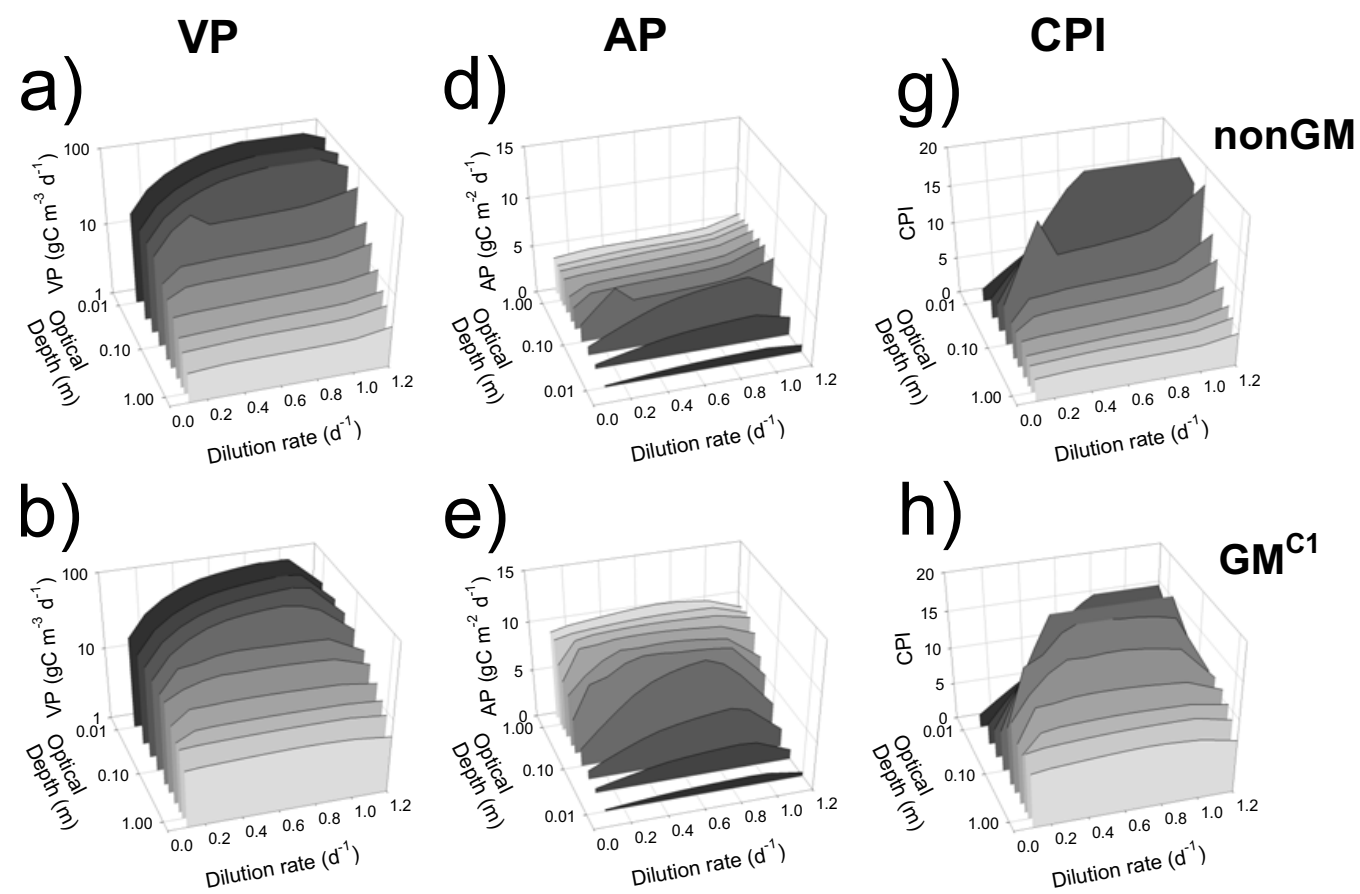

c)

f)
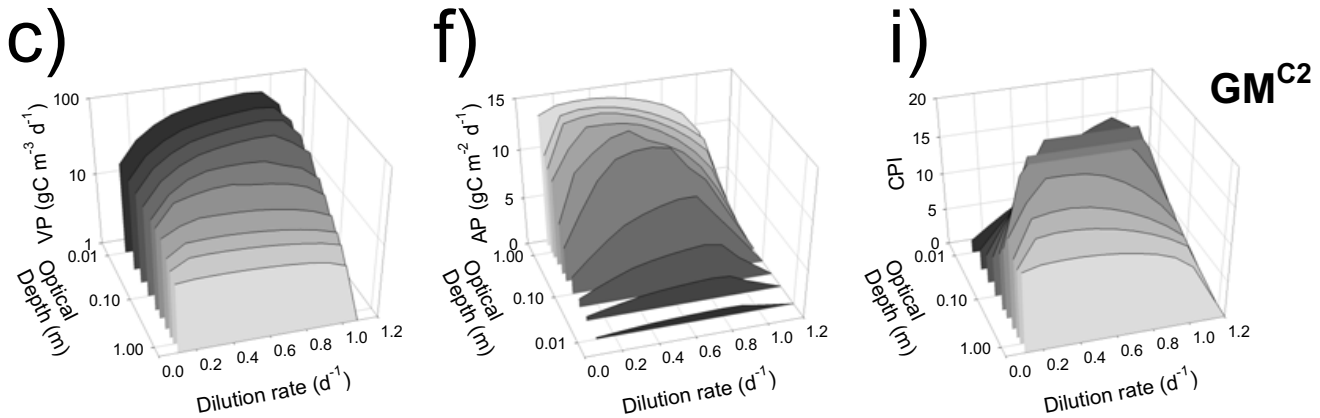

FIG. 2 

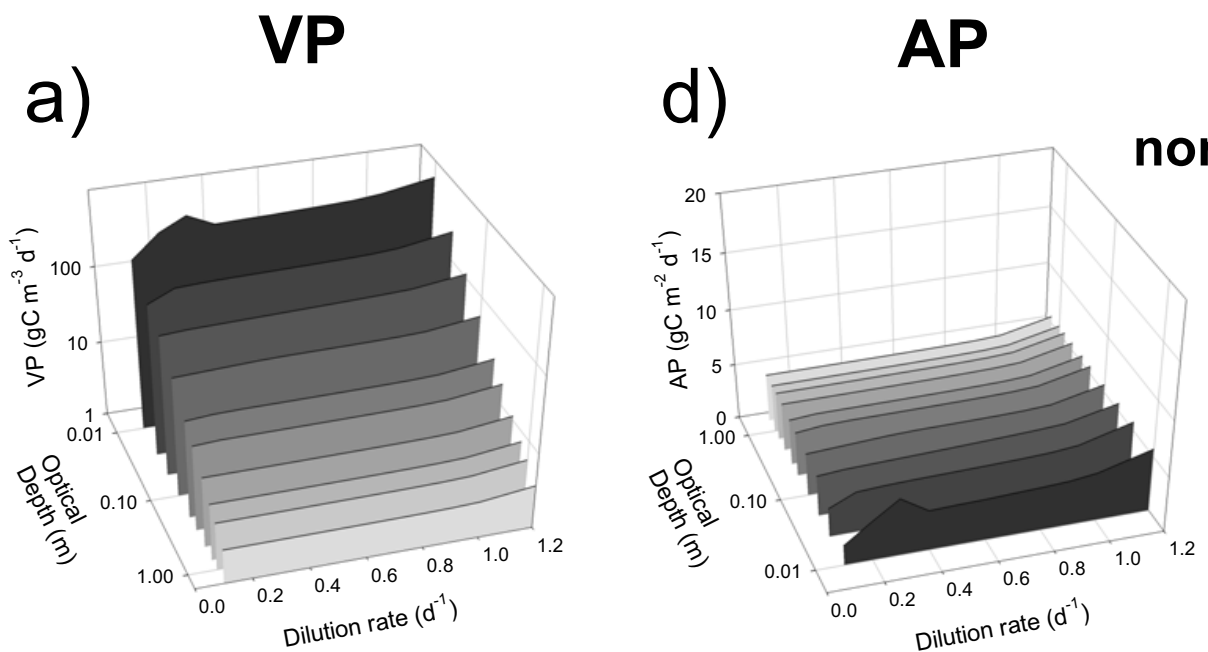

b)

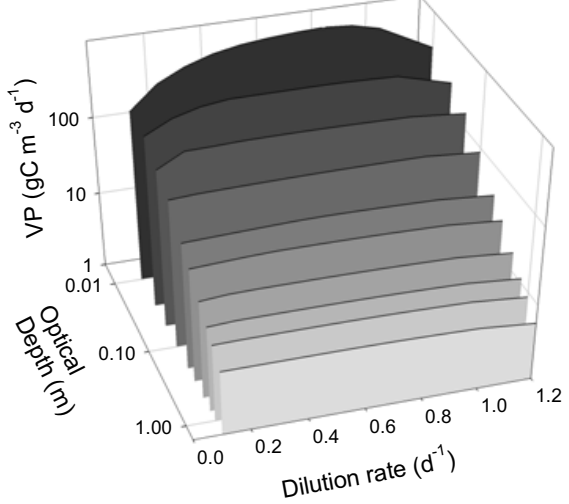

e)

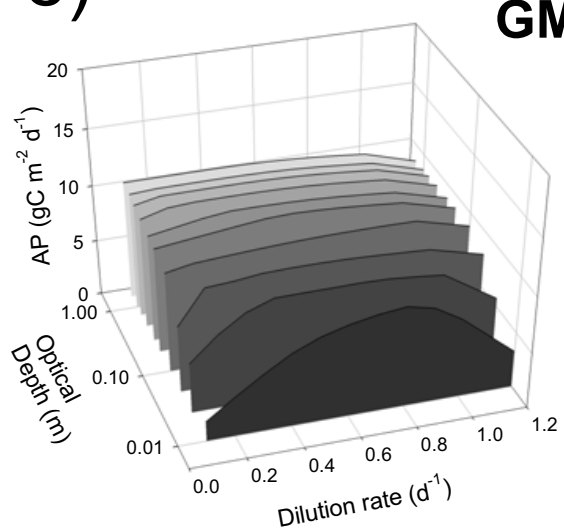

c)

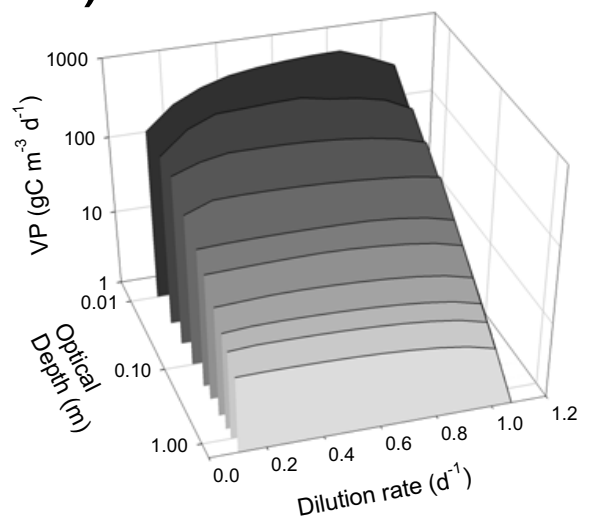

f)

$G M^{C 2}$

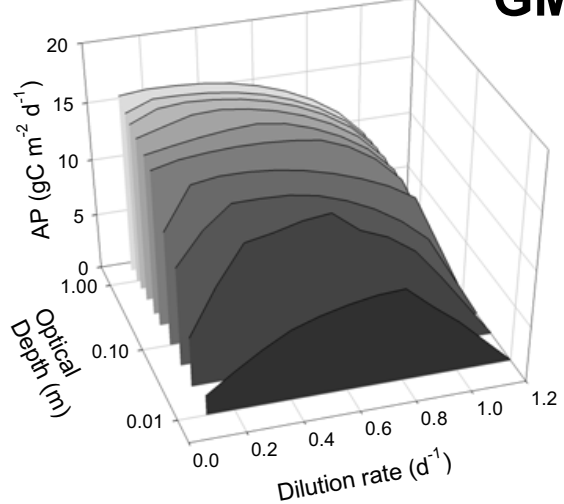

FIG. 3 
a)

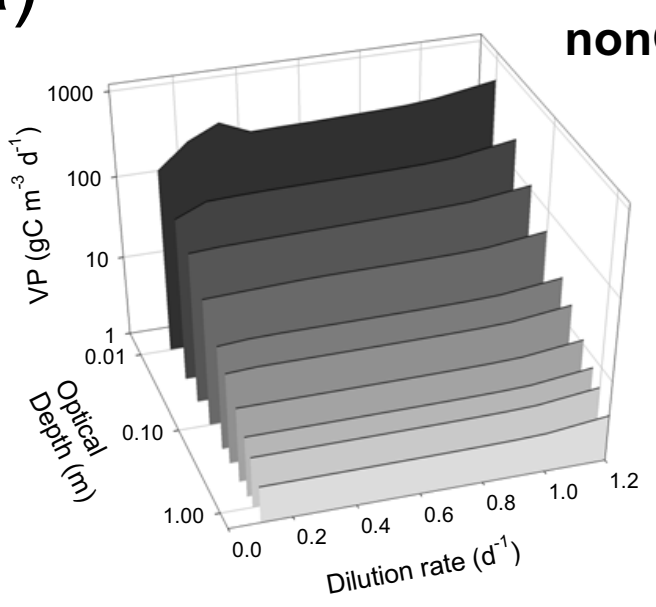

b)

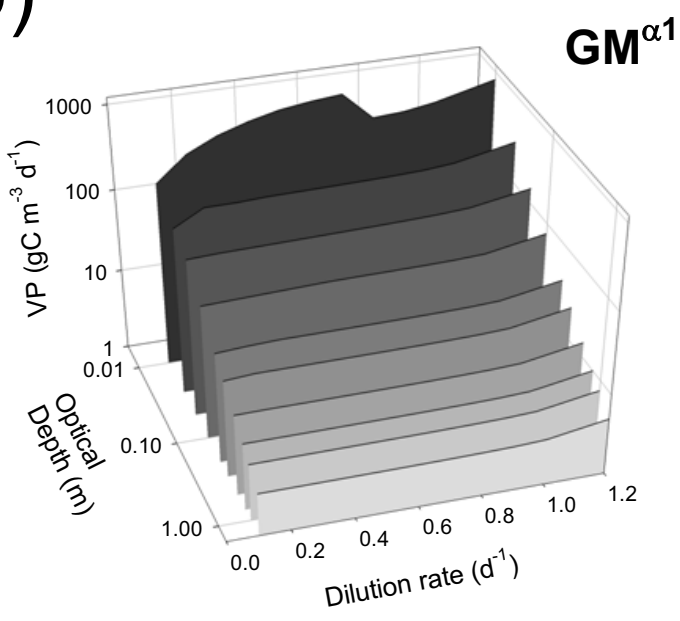

c)

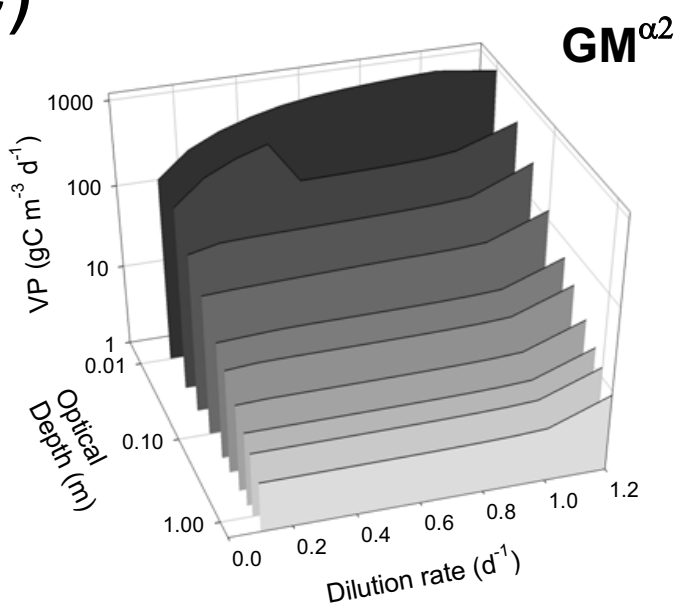

FIG. 4 

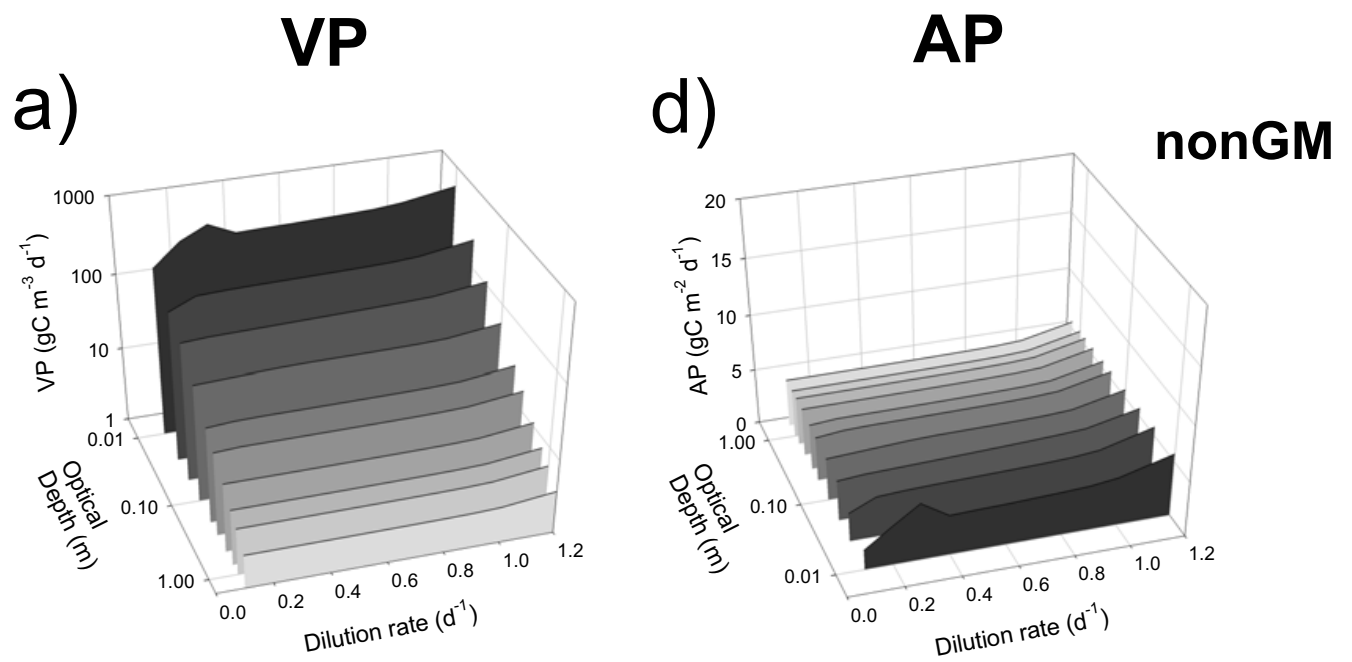

b)

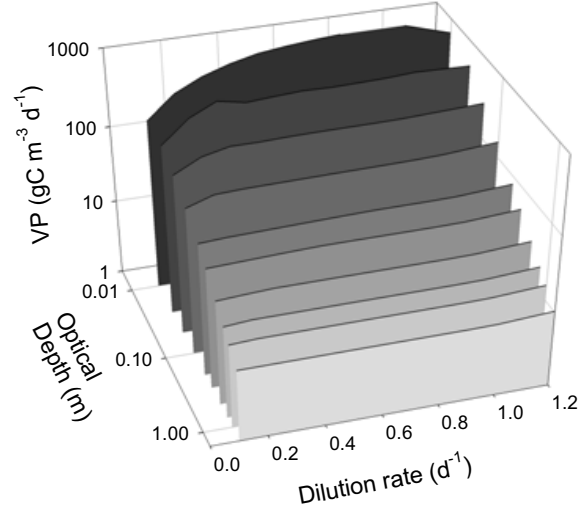

c)

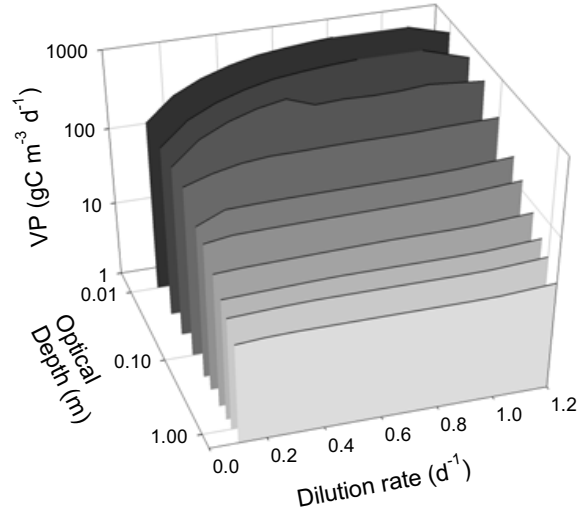

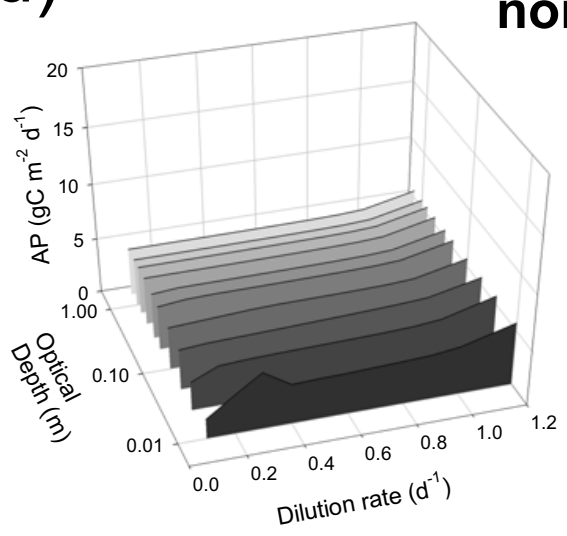

e)

$G M^{\mathrm{C} 1 \alpha 1}$

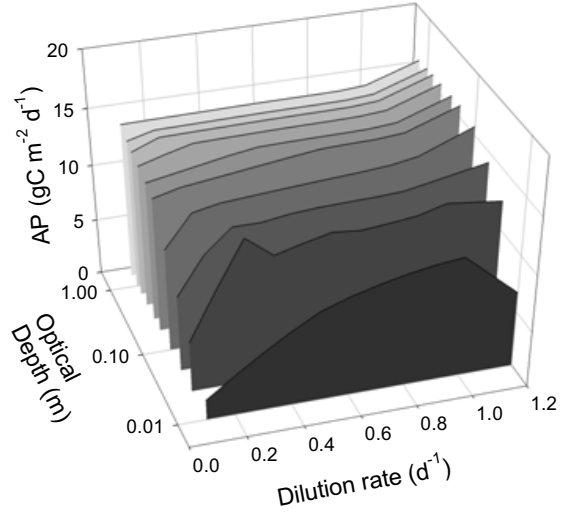

f)

$\mathbf{G M}^{\mathrm{C2 \alpha 2}}$

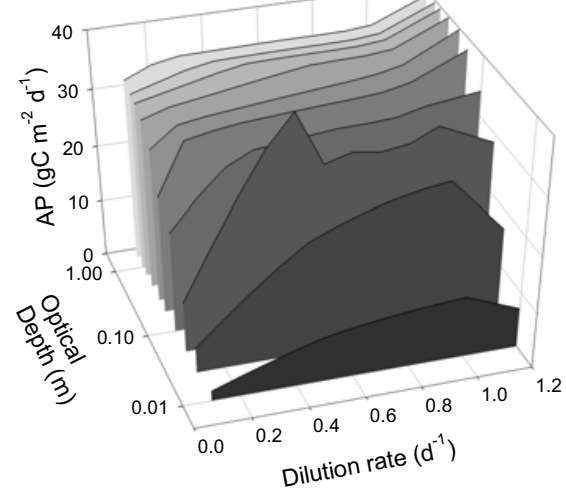

FIG. 5 
a)

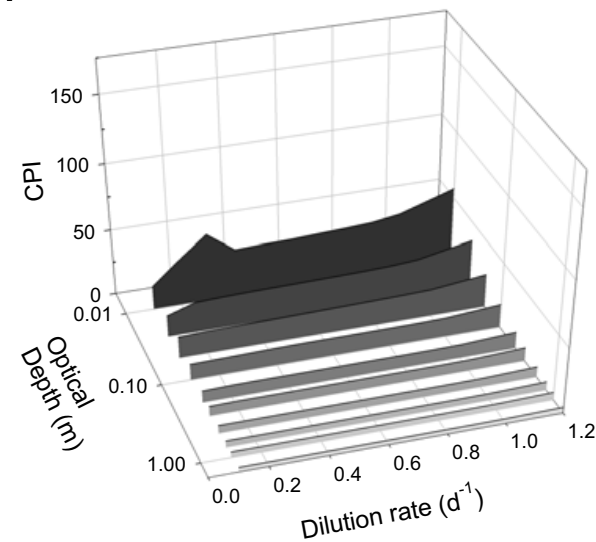

b)

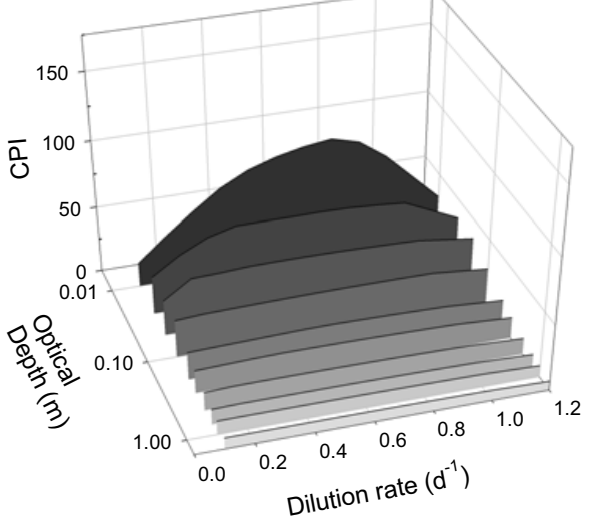

c)

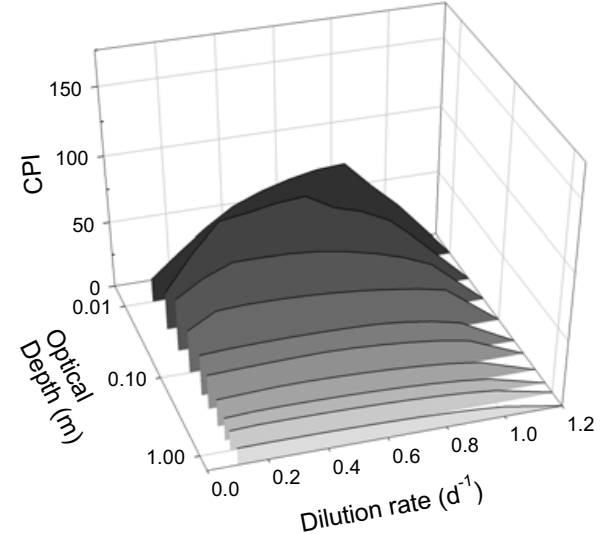

a) $\mathrm{GM}^{\alpha 1}$

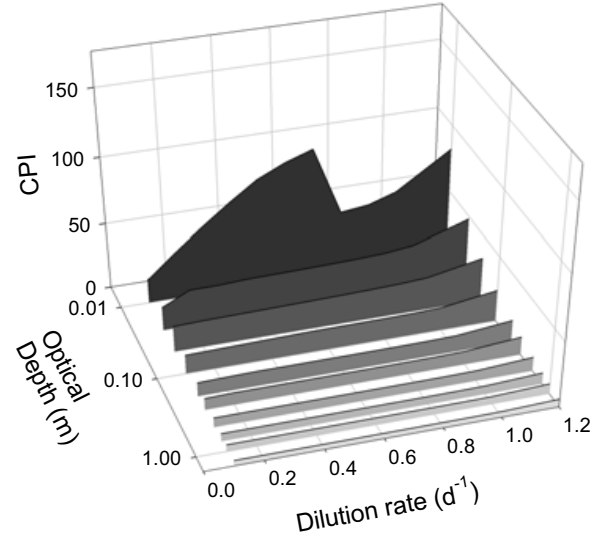

e)

$\mathrm{GM}^{\alpha 2}$

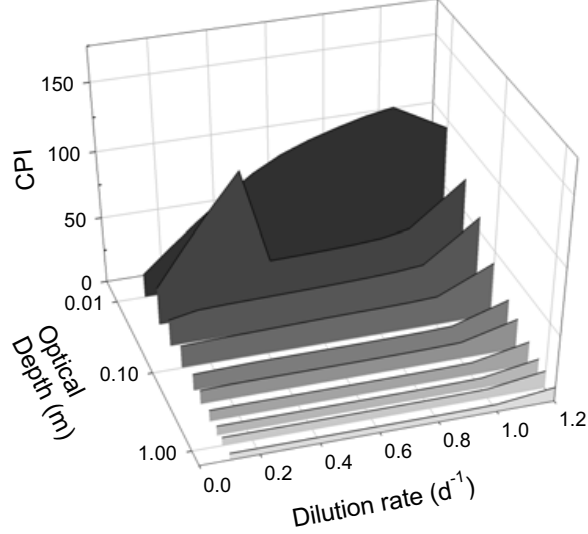

f)

$\mathrm{GM}^{\mathrm{C} 2 \alpha 2}$

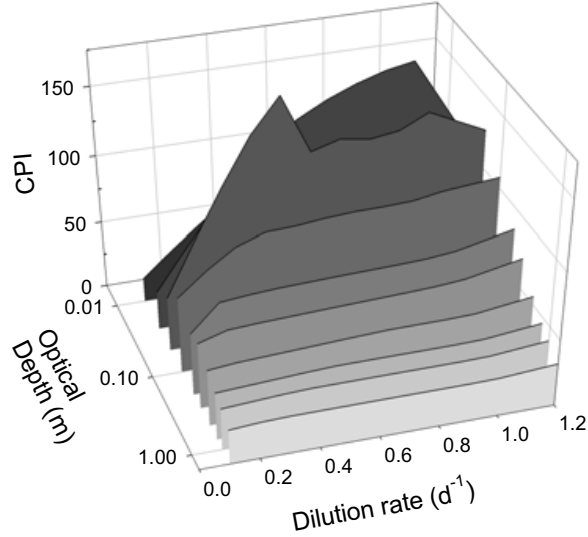

FIG. 6 
a)

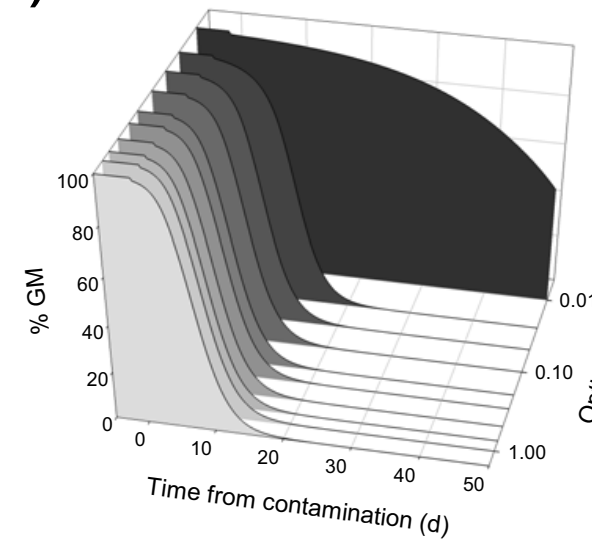

d) $\mathrm{GM}^{\mathrm{C} 2}$ into nonGM

b)

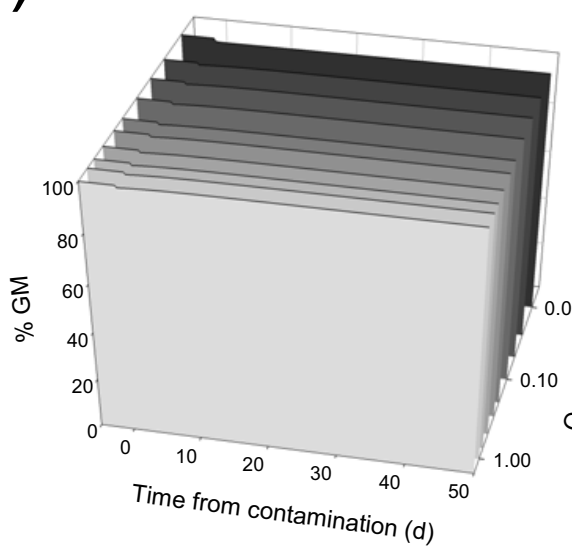

e)

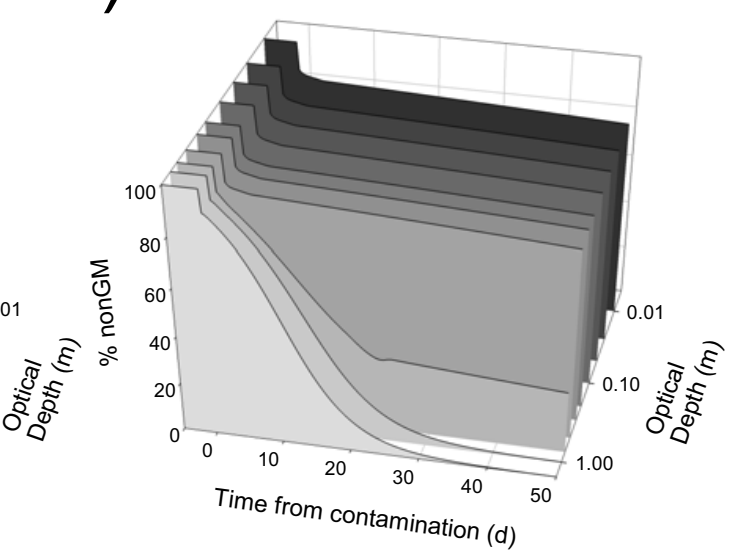

c)

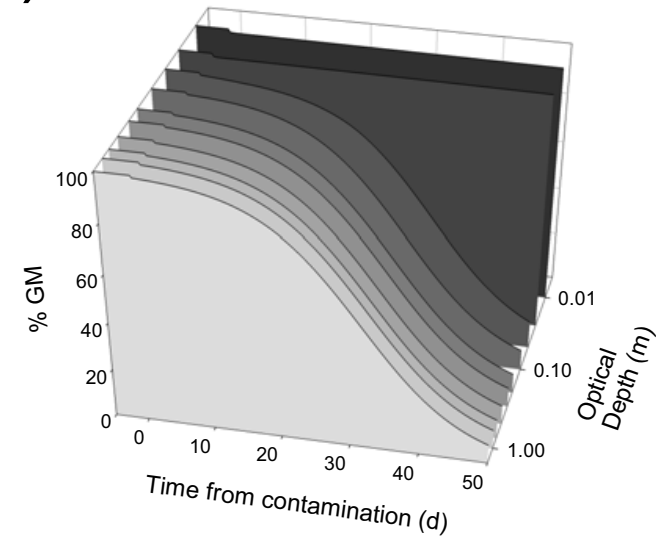

f) $\mathrm{GM}^{\mathrm{C} 2 \alpha 2}$ into non $\mathrm{GM}$

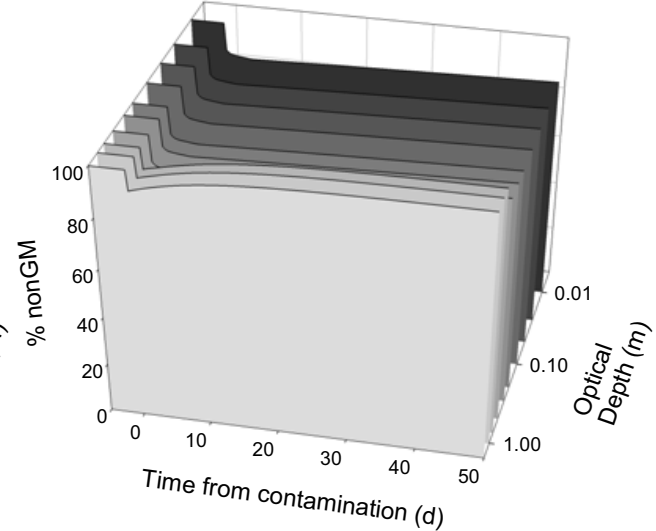

FIG. 7 
Table 1.

\begin{tabular}{llc} 
Organism & Chl: $\mathbf{C}_{\max }$ & $\boldsymbol{\alpha}^{\text {Chl }}$ \\
designation & & 7 \\
\hline nonGM & 0.06 & 7 \\
$\mathrm{GM}^{\mathrm{C} 1}$ & 0.015 & 7 \\
$\mathrm{GM}^{\mathrm{C} 2}$ & 0.006 & 14 \\
$\mathrm{GM}^{\alpha 1}$ & 0.06 & 35 \\
$\mathrm{GM}^{\alpha 2}$ & 0.06 & 14 \\
$\mathrm{GM}^{\mathrm{C} 1 \alpha 1}$ & 0.015 & 35 \\
$\mathrm{GM}^{\mathrm{C} 2 \alpha 2}$ & 0.006 &
\end{tabular}


Table 2.

\begin{tabular}{lll}
$\begin{array}{l}\text { Original } \\
\text { organism }\end{array}$ & $\begin{array}{l}\text { Contaminating organism and } \\
\text { additions as \% original biomass }\end{array}$ & $\begin{array}{l}\text { nutrient } \\
\text { concentrations } \\
\text { relative to f-medium }\end{array}$ \\
\hline $\mathrm{GM}^{\mathrm{C} 2}$ & nonGM at $1 \%$ & $5 \mathrm{f}$ \\
$\mathrm{GM}^{\alpha 2}$ & nonGM at $1 \%$ & $5 \mathrm{f}$ \\
$\mathrm{GM}^{\mathrm{C} 2 \alpha 2}$ & nonGM at $1 \%$ & $5 \mathrm{f}$ \\
nonGM & $\mathrm{GM}^{\mathrm{C} 2}$ at $10 \%$ & $\mathrm{f} / 0.2$ \\
nonGM & $\mathrm{GM}^{\alpha 2}$ at $10 \%$ & $\mathrm{f} / 0.2$ \\
nonGM & $\mathrm{GM}^{\mathrm{C} 2 \alpha 2}$ at $10 \%$ & $\mathrm{f} / 0.2$
\end{tabular}

